\title{
Ohlédnutí za 50letým vývojem oboru „správní právo“ a katedry správní vědy a správního práva
}

\section{Looking Backfor 50 years of Development in the Field of „Administrative Law“ and the Department of Administrative Science and Administrative Law}

\author{
Petr Průcha*
}

\begin{abstract}
Abstrakt
Přspèvek, poskytuje pobled jeho autora na 50letý vývoj oboru „správni právo" a Katedry správni védy a správního práva na Právnické fakultè Masarykovy univerzity. Postupně v několika návazných časových etapách tohoto vývoje poukazuje na personálni obsazeni katedry, zaměreni výuky, védecko-výzkumnou čnnost i celkový rozvoj oboru. Př̀spèvek se opirá o známé ci doložitelné faktografické údaje, presto je v̌sak. prevážně osobnim pobledem a výpovédi autora o prïpominaných skutečnostech.
\end{abstract}

\section{Klíčová slova}

Konstituováni katedry; základy a rozvoj oboru správni véda a správni právo; koncipováni a zamèreni výuky; védecko-výzkumná cinnost; personální vývoj obsazeni katedry; kvalifikačni rüst členü katedry; vazba katedry a oboru na společenskou praxi.

\section{Abstract}

The paperprovides the author's view of the 50 years development of the field of "Administrative Law" and the Department of Administrative Science and Administrative Law at the Faculty of Science, Masaryk University in Brno. Gradually in several consecutive time intervals of this development points out the staffing of the department, the focus of teaching, scientific research activities and the overall development of the field. The paper is based on known or substantiated factual data, but it is nevertheless mostly personal view and the author's statement about the facts mentioned above.

\section{Keywords}

The Constitution of the Department; Fundamentals and Development of the Disciplines Administrative Science and Administrative Law; Design and Focus of Teaching; Scientific Research; Personnel Development of the Department; Qualification Growth of the Department Members; the Relation of the Department and Discipline to Social Practice.

Moderní doba, ve které žijeme, je mj. příznačná rychlým životním tempem, a ve spojení s tím se jeví téměř neuvěřitelné, že uplynulo již 50 let od znovuobnovení naší právnické fakulty a současně také téměr 50 let od mého příchodu na tuto fakultu.

\footnotetext{
* Prof. JUDr. Petr Průcha, CSc., Katedra správní vědy a správního práva, Právnická fakulta, Masarykova univerzita, Brno / Department of Administrative Studies and Administrative Law, Faculty of Law, Masaryk University, Brno, Czech Republic / E-mail: Petr.Prucha@law.muni.cz
} 
Takovéto časové odstupy a výročí již samy o sobě přímo vybízejí k ohlédnutí zpět a připomenutí si průběhu jednak osobního působení na fakultě, a to ve spojení s oborem svého působení, jímž je „správní právo“, a také s jeho dosavadním 50letým vývojem. Je proto myslím také dobrým počinem fakulty, že iniciovala vydání celého tohoto vzpomínkového časopiseckého „čísla“.

Hned na tomto místě považuji především za nutné poznamenat, že následující „ohlédnutí“ není exaktní dokumentací či analýzou, ale je volným zprostředkováním toho, co mi utkvělo v paměti ze svého působení, a vychází tedy v převážné míre z osobních vzpomínek, a co se potom v podstatně menší míře opírá o doložitelné písemné prameny. Začít musím tím, že na fakultě jsem začal studovat v r. 1971 po absolvovaných ústních přijímacích zkoušek. Náš studijní ročník byl v pořadí třetím rozbíhajícím se ročníkem po znovuotevření fakulty v r. 1969. Tehdejší systém studia počítal mj. se stálými seminárními skupinami, seminárními vedoucími (z řad studentů) a s ročníkovými učiteli (brzy přistoupil i institut skupinových učitelů). Tuto poznámku uvádím proto, že právě tyto skutečnosti napomohly mému prvnímu osobnímu kontaktu s katedrou správní vědy a správního práva.

Hned na počátku studia jsem byl jmenován vedoucím seminární skupiny (a zůstal jím po celou dobu pětiletého studia), do níž jsem byl zařazen, a jako ročníková učitelka našeho ročníku byla ustanovena Milada Plšková, která působila právě na katedře správní vědy a správního práva a věnovala se oboru správní právo. Jako vedoucí seminárních skupin z ročníku jsme s ročníkovou učitelkou mívali občasné organizační schůzky, a ty se konaly v pracovně Milady Plškové na prŕíslušné katedře. V těchto prostorách jsem se také záhy začal potkávat s Jiřím Klestilem, který se na dané katedře, jak jsem brzy zjistil, podílel na výuce předmětu správni věda. Tento předmět byl zjednodušeně řečeno koncipován jako aplikovaná obecná teorie ř́zení a teorie organizace na problematiku státní správy. To mne bezprostředně oslovilo, nebot' jako absolvent střední průmyslové školy strojnické jsem k tomuto předmětu měl blízko, nebot' v rámci středoškolského studia jsme teorii ř̌zeni a organizace, byt' se zaměřením na průmyslové podniky, měli součástí našeho tamního studijního programu. Můj zájem o tento předmět potom vedl k tomu, že od svého třetího ročníku studia na právnické fakultě jsem u Jiř́ho Klestila pracoval jako pomocná vědecká síla, v pátém ročníku studia jsem již působil na poloviční úvazek jako lektor a bezprostředně po ukončení studia v r. 1976 jsem se potom stal celoúvazkovým členem katedry správní vědy a správního práva, na které působím dosud.

Katedra správní vědy a správního práva byla od samého znovuotevření fakulty v r. 1969 samostatnou katedrou. V době mého příchodu na fakultu byl jejím vedoucím Miloslav Máša, který tuto funkci zastával až do r. 1990 a který se jí ujal v r. 1970¹ po Jaroslavu

1 Miloslav Máša byl v době svého příchodu na právnickou fakultu docentem (přišel z Vojenské akademie A. Zápotockého), bezprostředně po nástupu byl jmenován tzv. mimořádným profesorem a po nabytí účinnosti zákona č. 39/1980 Sb., o vysokých školách, se postavení mimořádných a řádných profesorů sjednotilo a Miloslavu Mášovi poté př́íslušel titul „profesor“. 
Pošvářovi. Jaroslav Pošvář byl na znovuotevřené fakultě historicky prvním vedoucím katedry správní vědy a správního práva, tuto funkci však vykonával jen v průběhu let 1969-1970, kdy na podzim r. 1970 musel fakultu opustit z věkových důvodů s ohledem na dopad tehdejší novelizující zákonné úpravy. Jaroslav Pošvář patřil k několika málo profesorům brněnské právnické fakulty, kteří se po jejím zrušení v r. 1950 ještě dožili jejího znovuotevření v r. 1969 a kteří zde určitý čas také ještě pedagogicky působili. ${ }^{3}$

Působení Jaroslava Pošváře na katedře správní vědy a správního práva po znovuotevření právnické fakulty v r. 1969, byt’ bylo velmi krátké, katedře nezastupitelně vtisklo její profilový ráz, nebot' se od svého samotného počátku věnovala vedle oboru správní právo také oboru správni véda. Ostatně takto orientované oborové zaměření Jaroslava Pošváře je doložitelné již z jeho předchozího poválečného působení na brněnské právnické fakultě. Jmenovitě ze studijního programu Masarykovy university ve školním roce 1947/1948 se podává, že Jaroslav Pošvář na její právnické fakultě působil jako ředitel Ústavu pro správní vědu a právo správní a měl vypsány přednášky a semináře v předmětech: správní právo, správní rízení a správní věda. ${ }^{4}$

Takto nastavené zaměření oborů katedry již však Jaroslav Pošvář vzhledem ke svému odchodu do „penze“ nestihl pedagogicky „rozběhnout“, nicméně ku zřejmému prospěchu věci toto zaměření oborů v plném rozsahu akceptoval bezprostředně navazující vedoucí katedry Miloslav Máša. A v podstatě teprve on, a to i s ohledem na posloupný časový náběh výuky $\mathrm{v}$ jednotlivých studijních ročnících (výuka správní vědy byla v té době zařazena do čtvrtého semestru, výuka správního práva potom do pátého a šestého semestru), reálně nastavil a posléze dále rozvíjel jmenovitou obsahovou náplň obou těchto oborů, a to jak v rovině pedagogické, tak v rovině vědecké.

Stejně tak je se jménem Miloslava Máši spojeno i prvotní personální obsazení katedry a jeho následné dotváření. Miloslav Máša nastoupil na katedru v r. 1970 k Jaroslavu Pošvářovi a po jeho odchodu do penze Miloslava Mášu, a to již jako představitele oboru, v podstatě časově bezprostředně doplnili Jiř́ Klestil, Milada Plšková, Milan Navrkal a Milan Polián. Od počátku působení katedry na znovuotevřené právnické fakultě katedra správní vědy a správního práva vedle oborů seznatelných z jejího názvu měla za úkol současně zabezpečovat také finanční právo. Pro potřeby oboru finanční právo byl na katedru již v r. 1971 přijat Vladimír Zahálka. ${ }^{5} \mathrm{~V}$ tomto personálním obsazení katedra působila prakticky beze změny do poloviny sedmdesátých let.

2 Zákon č. 163/1969 Sb., kterým se měnil a doplňoval zákon č. 19/1966 Sb., o vysokých školách.

3 Bližze viz PRŮCHA, P. a K. SCHELLE. Život a dílo prof. JUDr. Jaroslava Pošváré, CSc., Brno: MU, 1993, s. 3 a násl.

4 Seznam prènášek na Masarykově universitě v Brně, v żimním bẻbu studijníbo roku 1947-1948. Nákladem Masarykovy university v Brně - Tiskl Melantrich v Brně, 1947, s. 8 a 10.

5 Později, a to od 1. 7. 1979, byl obor finanční právo převeden na tehdejší katedru hospodářského práva, na kterou přešel i Vladimír Zahálka. 
V tomto období, tj. v první polovině 70. let, byla na katedře základním způsobem nastavena výuka jednotlivých předmětů, byla zpracována základní studijní literatura, postupně se rozvijely další formy práce se studenty, (práce s pomocnými vědeckými silami, SVOČ), stejně jako se položily základy a začaly se rozvíjet formy tehdejší vědecko-výzkumné práce.

Toto období mám uchováno v paměti z pohledu svého postavení studenta a současně i pomocné vědecké síly na katedře. $V$ pořadí první předmět katedry, s nímž se studenti tehdy setkávali ve výuce, byla správni věda. Přednášky vedl převážně Miloslav Máša, částečně i Jiří Klestil, který současně v té době také vedl všechny semináře. ${ }^{6}$ Jak již bylo shora poznamenáno, tento předmět byl od počátku jeho zavedení katedrou prezentován jako na státní správu aplikovaná obecná teorie rrízení a teorie organizace. Jako základní studijní literatura $\mathrm{k}$ předmětu správní věda byla (vedle další literatury rozšiřujícî) předepsána Mášova učebnice s názvem Teorie řízení a správy, která byla zpracována právě pro tento účel a byla vydána UK Praha hned v r. $1970 .^{7}$

Pro lepší představu a dokreslení zaměření daného předmětu lze připomenout alespoň základní obsahovou strukturu dané učebnice. Učebnice měla devět obsahových částî s názvy: Obsah a prèdpoklady ř́dici činnosti, Hlavni smèry v teorii ř́zení, Hlavni tendence védeckébo řzeni a správy, Lidský činitel v řzeni a správé, Hlavni činnosti (funkce) v procesu rízeni, Vybrané otázky teorie organizace, Sociometrické metody rízení, Praxeologie jako obecná teorie rízeni, Kybernetický prǐstup $k$ řřzení. Všechny tyto části, resp. kapitoly byly prrirozeně dále ještě podrobněji obsahově členěny, učebnice byla doplněna výčtem navazující základní literatury, přičemž doporučená literatura ke studiu byla pochopitelně průběžně ještě dále doplňována a aktualizována. Z daného období tak je třeba, prŕkladmo za všechny, zejména poukázat na Mášův článek vymezující vztah správní vědy a správního práva. ${ }^{8}$ Podání obsahu daného předmětu ve výuce přitom akcentovalo průmět dané problematiky do oblasti státní správy a bylo tak cíleně prezentováno jako propedeutické pro navazující výuku práva správního.

Výuka správního práva potom byla již v daném období rozdělena na (jednosemestrálnî) výuku jeho tzv. obecné části, která tehdy zahrnovala i pedagogické zprostředkování tzv. správního práva procesního, a dále na výuku (taktéž jednosemestrálnî) tzv. zvláštní

6 Jiř́i Klestil tehdy na katedře setrval do r. 1975, kdy byl nucen z fakulty odejít, a to z důvodů personálně politických, což nezo̊stalo bez odezvy na jeho zdravotním stavu. V té době, a také v dané souvislosti, mi bylo jako studentovi posledního ročníku studia nabídnuto místo lektora na částečný pracovní úvazek s tím, zda bych, jako víceletá pomocná vědecká síla Jiřího Klestila, po něm nepřevzal vedení dané seminární výuky. To jsem také, po předchozí konzultaci se samotným Jiřím Klestilem, a také v návaznosti na jeho osobní doporučení, nakonec učinil, přičemž jsem toto cítil jako jistý osobní závazek vưči němu, jehož jsem považoval ze mně nejbližšího člověka z katedry a velice si jej vážil. O to více jsem uvítal, když se v r. 1990 Jiří Klestil na fakultu opět vrátil, byt' na jinou katedru (katedra národního hospodářství).

7 MÁŠA, M. Teorie ř́zení a správy. Praha: Univerzita Karlova, 1970, 228 s.

8 MÁŠA, M. Správní věda a její vztah ke správnímu právu. Správní právo, 1971, č. 7, s. 396. 
části správního práva, která byla představována správním právem hmotným a zahrnovala výklad základních institutů jak organizace, tak potom zejména činnosti státní správy na jejích vybraných rezortních úsecích. Přednášky z obecné části správního práva v dané době vedl prakticky výlučně Miloslav Máša, přednášky ze zvláštní části správního práva v převažujícím rozsahu vedl Milan Polián, ${ }^{9}$ některá témata přednášel rovněž Miloslav Máša a také Milada Plšková. Na seminární výuce se tehdy podíleli Milan Polián, Milada Plšková a Milan Navrkal. Pokud šlo o studijní literaturu, nutno uvést, že obdobně jako v př́padě správní vědy, katedra prakticky od svého vzniku disponovala vlastní učební pomůckou pro správní právo - obecnou část, jejímž autorem byl opět Miloslav Máša. ${ }^{10}$ Taktéž pro lepší představu a dokreslení daného předmětu se nabízí uvést, jak bylo dané „skriptum“ obsahově pojednáno - text byl rozdělen do čtyř obsahových částí s názvy: Základni otáaky teorie správního práva, Organizace státni správy, Kontrola státni správy a Správní právo procesní. Přirozeně i tyto rámcově označené obsahové části byly vnitřně detailněji členěny a kromě další doporučované literatury zaměření předmětu předpokládalo, a také vyžadovalo, aktivní práci s platnou právní úpravou. Zaměření studia na danou právní úpravu se nejvýrazněji projevovalo v seminární výuce a př́pravě na ni. To potom ve zvýšené míre platilo zejména ve spojení s výukou a studiem tzv. zvláštní části správního práva. Tady až do r. 1975 katedra vlastní učební pomůckou nedisponovala a studentům byla ke studiu doporučována tehdejší př́íslušná učební pomůcka „pražskáa“. ${ }^{11} \mathrm{~V}$ r. 1975 potom Miloslav Máša již zpracoval a nechal vydat první dobovou, byt' nejprve rámcovou, učební pomůcku $\mathrm{k}$ dané problematice, zaměřenou na její vybrané okruhy. ${ }^{12}$ Výuka však prritom byla obsahově pojímána podstatně šířeji, a to se zaměřením zejména na následující témata: správa na úseku národohospodárskébo plánování, správa na úseku sociálnè-ekonomických informací, finančni správa, celni správa, správa na úseku cen, správa na úseku investični výstavby, správa na üseku primyslu, správa na úseku zemèdèlstvi, správa na úseku dopravy, správa na üseku tæv. vnitrnich věci, správa na üseku bezpečnosti, správa na üseku obrany, správa na úseku školství, správa na úseku kultury a správa na úseku zdravotnictvi. Tomuto rozsahu výuky také korespondovala zvýšená hodinová dotace týdenní seminární výuky. Správní právo přitom bylo, počínaje státními závěrečnými zkouškami prvních absolventů fakulty v r. 1974, zařazeno jako povinný státnicový předmět.

Produkce prvních absolventů znovuotevřené brněnské právnické fakulty, což platilo i pro další cca tři - čtyři roky, byla příležitostí, a také reálně poskytla využitou možnost, pro personální dobudovávání kateder. Na katedru správní vědy a správního práva tak postupně nastoupili Miloš Jedlička (1974), já, resp. moje osoba (1975), a po odchodu Miloše Jedličky do praxe Jan Svatoň (1978). V r. 1978 z katedry odešel do praxe rovněž

9 Sám o sobě také občas poznamenával, že je „hmotař“.

10 MÁŠA, M: Správní právo. Obecná část. Brno: UJEP, 1971, $181 \mathrm{s.}$

11 KOLEKTIV. Správni právo - zulástní cást, Díl I. - III. Praha: ÚSS, 1971.

12 MÁŠA, M. Vybrané kapitoly ze zuláštni cásti správního práva. Brno: UJEP, 1975. 
Milan Navrkal a na katedru poté v r. 1980 přišla Helena Sýkorová. V průběhu 80. let na katedře rovněž působili někteři „stálejší“ externisté, $z$ nichž je třeba připomenout zejména Jiř́ho Gottweise, Jaromíra Kožouška, Antonína Mimochodka a Miroslava Pastyř́ka. Takto obsazený personální stav katedry zůstal, s výjimkou Heleny Sýkorové, která v r. 1985 přešla na Přírodovědeckou fakultu UJEP a na jejíž místo v r. 1986 nastoupila Dana Jarošová (Šrubařová), prakticky nezměněn až do r. 1990.

Počínaje druhou polovinou 70. let, resp. pro celé období druhé poloviny 70. let a léta 80. potom platilo, že katedra pedagogicky i vědecky navazovala na a rozvíjela to, co a jak bylo nastaveno a vytvářeno v prvních pěti letech její existence.

Jmenovitě se nabízí připomenout, že v oblasti výuky došlo počátkem druhé poloviny 70. let $\mathrm{k}$ přejmenování předmětu správni věda na předmět „,teorie řízení, přičemž po obsahové stránce byly nadále akcentovány státněsprávní aspekty, a současně byly některé žretelnější správněvědní instituty zařazovány do výuky správního práva. Přednášky předmětu teorie ř̌zeni dále většinově vedl Miloslav Máša a od r. 1978 po mně převzal seminární výuku v tomto předmětu nově nastoupivší Jan Svatoň (já jsem od té doby již převážně působil na oboru správní právo a ve výuce předmětu teorie řízení jsem nadále toliko „,vypomáhal“"). Pojem „správní věda“ však i poté zůstal součástí názvu katedry a stejně tak byla správní vědě a jejím tématům i nadále věnována poměrně výrazná pozornost ve vědecké a odborné literární produkci. To opět souviselo zejména s výraznými pracemi Miloslava Máši. ${ }^{13}$ Teorie řízení zůstala předmětem povinným a vzhledem $\mathrm{k}$ výukovému př́istupu i nadále způsobile plnila propedeutickou funkci ve vztahu k následné výuce předmětu správní právo. $\mathrm{K}$ tomu posloužila právě i výrazněji profilovaná Mášova studijní literatura (viz pozn. č. 13), která byla studentům doporučována $\mathrm{k}$ dalšímu doplnění titulu Teorie ř́zeni a správy.

Obsahové zaměření výuky správního práva potom bylo permanentně průběžně aktualizováno, a to s ohledem nejen na další nabíhající teoretické poznatky, ale dále pak zejména s ohledem na posloupné aktuální změny související právní úpravy. I v těchto letech platilo, že přednášky z obecné části správního práva $\mathrm{v}$ dané době nadále vedl prakticky výlučně Miloslav Máša, přednášky ze zvláštní části správního práva v převažujícím rozsahu vedl Milan Polián, některá témata přednášel také Miloslav Máša a Milada Plšková a ve druhé polovině tohoto období již i já. Na seminární výuce se tehdy podíleli všichni členové katedry.

Průběžná aktualizace obsahového zaměření vyučovaných předmětů se také promítala do aktualizace základní i doplňující studijní literatury. V oblasti obecné části správního práva Miloslav Máša zpracoval a nechal vydat v r. 1975 druhé přepracované vydání svého „skripta“ k obecné části správního práva a v r. 1980 poté ještě jeho třetí přepracované vydání. ${ }^{14} \mathrm{O}$ rok později se potom Miloslav Máša také spoluautorsky podílel na celostátní

13 Zejm. MÁŠA, M. Něketeré teoretické otázky socialistické sprámín védy. Brno: UJEP, 1980; MÁŠA, M. Socialistická spráni véda. Brno: UJEP, 1985, $175 \mathrm{~s}$.

14 MÁŠA, M. Spráuní právo. Obecná cást. Brno: UJEP, 1975, 1980. 
učebnici obecné části správního práva. ${ }^{15} \mathrm{~V}$ r. 1984 Milada Plšková zpracovala „skriptum“ pro potřeby praktických cvičení ze správního práva, ${ }^{16}$ v r. 1985 pak Miloslav Máša zpracoval jako samostatnou učební pomůcku „skriptum“ ke správnímu právu procesnímu. ${ }^{17} \mathrm{~V}$ oblasti tzv. zvláštní části správního práva bylo nejprve pod vedením Miloslava Máši v r. 1977 vydáno obsažnější „skriptum“, ${ }^{18}$ které bylo později, vedle svých následných aktualizací, ještě doplněno „,sektorovou“ učební pomůckou zpracovanou ve dvojici Miloslav Máša - Milan Polián. ${ }^{19} \mathrm{~V}$ závěru osmdesátých let potom také následovala kolektivní učební pomůcka pro potřeby seminárních praktických cvičení. ${ }^{20}$

Za poznamenání nepochybně stojí, že v celém tomto období, a to prakticky počínaje druhou třetinou 70 . let, byla $\mathrm{v}$ pedagogické oblasti věnována výrazná pozornost práci se studenty $v$ rámci SVOC. Katedra tradičně mívala vlastní odbornou sekci v průměru s dvanácti až patnácti individuálními či kolektivními soutěžními pracemi a její soutěžící studenti se obvykle velmi úspěšně umíst’ovali i v rámci celostátních kol SVOČ. Na této práci se aktivně podíleli jako konzultanti prakticky všichni členové katedry, přičemž nezastupitelná míra práce a odpovědnosti za organizační prrípravu běhu sekce v rámci fakultního kola (popř. celostátního kola tam, kde byla fakulta jeho organizátorem - jednou za čtyři roky v algoritmu Praha, Brno, Bratislava, Košice) spočívala na organizačním katedrovém garantovi. Tuto funkci zpočátku zastávala Milada Plšková, později jsem byl tímto garantem já, resp. se o tuto funkci či práci dělil s Janem Svatoněm. Při mém osobním subjektivním zpětném pohledu na tuto oblast, tzn. jak byla daná studentská soutěž celkově vnímána, jaká jí byla věnována pozornost a jak také daná konkrétní soutěžní kola probíhala, musím konstatovat, že šlo o na svoji dobu velice významnou a fundovanou formu práce se studenty. O soutěž byl mezi studenty značný zájem, šlo o soutěž prestižní, soutěž byla brána všemi velice vážně a umístění studentů na čelných místech bylo v celé fakultní akademické obci vysoce ceněno i neformálně. V této souvislosti není také bez zajímavosti, že několik nejúspěšnějších soutěžících, a to zejména hned z prvních cca pěti let soutěže, po absolvování studia doplnilo mj. řady vysokoškolských pedagogů přímo na naší fakultě. Celofakultní garantkou SVOČ byla po Břetislavu Ulmanovi (druhá polovina sedmdesátých let) celá osmdesátá léta Zdeňka Gregorová. Díky jejím mimořádným organizačním schopnostem, jejímu zájmu a značnému zaujetí pro tuto činnost, dosáhla organizace SVOČ na naší fakultě v té době nadprůměrného ohlasu.

15 LUKEŠ, Z. a kol. Ceskoslovenské správni právo. Praha: Panorama, 1981.

16 PLŠKOVÁ, M. Praktikum ze správního práva. Praha: SPN, 1984.

17 MÁŠA, M. Správní právo procesní. Brno: UJEP, 1980.

18 MÁŠA M. a kol. Československé správni právo. qulástni cáast. Brno: UJEP, 1977.

19 MÁŠA, M. a M. POLIÁN. Správni právo v oblasti sociálně kulturní. Brno: UJEP, 1981.

20 POLIÁN, M., M. PLŠKOVÁ, P. PRU゚CHA a J. SVATOŇ. Vybraná témata pro cvičení ze správního práva hmotnébo. Brno: UJEP, 1988. 
S ohledem na oborové zaměření naší katedry je dále třeba připomenout také její podíl na př́pravě, organizaci a vyhodnocování tzv. odborné praxe studentů, předepisované studijními programy. Jednalo se o odbornou praxi, kterou studenti vykonávali v oblasti státní správy, a to ponejvíce ve sféře tehdejších národních výborů. I do této práce katedry byli zapojováni prakticky všichni její členové a opět i tady největší tíha práce a odpovědnosti náležela organizačnímu garantovi. Také tuto práci měla, a to prakticky po celou dobu až do r. 1990, na starosti Milada Plšková, a to žrejmě zejména s ohledem na její bližší odborný zájem o problematiku národních výborů.

Katedra, resp. její členové, v celém připomínaném období (od poloviny 70. let do r. 1990) průběžně vyvíjela i zřetelehodnou vědecko-výzkumnou činnost. V dané době se jednalo o aktivní zapojení členů katedry do řešení úkolů tzv. státního plánu vědeckého výzkumu a také o soustavnou spolupráci se společenskou praxí, a to jak na úrovni ústřední, tak také na úrovni tehdejších národních výborů, a to všech jejích stupňů. Za připomenutí v tomto směru stojí, že Miloslav Máša svoji vědeckou činnost orientoval zejména na účast na legislativní tvorbě, kdy po dobu více než 15 let zastával funkci předsedy Stálé pracovní komise pro správní právo Legislativní rady federální vlády. Mimo to zastával nejrůznější funkce $\mathrm{v}$ některých dalších centrálních orgánech či celostátních komisích, které se vědecky či jinak odborně zaměřovaly na problematiku státní správy či správního práva. Byl tak celorepublikově uznáván pro svůj zřejmý vědecký přínos v oblasti teorie správního práva, a to zejména pokud šlo o koncepci správního práva procesního, právní formy a metody činnosti státní správy a její kontrolu. ${ }^{21}$ Mimořádný byl dále potom jeho přístup $\mathrm{k}$ řešení řady správněvědních témat ve spojení s teoretickým rozpracováním organizačních i funkčních předpokladů zvyšování efektivnosti státní správy. Miloslav Máša také, a to prakticky jako jediný z učitelů katedry do r. 1990, vedl tzv. aspirantskou výchovu (k získání vědecké hodnosti „CSc.“). Z učitelů katedry jsem touto vědeckou výchovou u Miloslava Máši prošel já a dále Jan Svatoň. Milan Polián se v dané době teoreticky zabýval problematikou organizace státní správy ve spojení s jejím federálním modelem a dále pak také správou zemědělství, se zvláštním zřetelem k výkonu tzv. správního dozoru. Milada Plšková se pak komplexně zabývala výkonem státní správy národními výbory a Milan Navrkal se výrazněji věnoval správě školství. Já jsem se v té době zabýval metodami a formami činnosti veřejné správy a dále správně právní odpovědností. Jan Svatoň se zaměřoval na organizační problematiku státu s bližším zaměřením na organizační i funkční pojetí veřejné správy a jejich subjektů.

$S$ vědeckou činností členů katedry také souvisela jejich poměrně frekventovaná publikační činnost, a to jak pokud šlo o vědecké či jinak odborné monografie, tak také pokud šlo o odborné časopisecké články a odborné příspěvky pro vystoupení na vnitrostátních i mezinárodních konferencích. $\mathrm{V}$ dané době byly v rámci katedry také organizovány a realizovány četnější mezinárodní styky, kdy katedra jednak sama přjímala pracovníky

21 Ročenka Univerzity Jana Evangelisty Purkyně v Brně 1976-1985. Brno: UJEP, 1987, s. 457-459. 
nejrůznějších zahraničních vysokoškolských pracovišt’ a kdy dále také učitelé katedry naopak, a to poměrně četně a pravidelně, vyjížděli ke studijním i přednáškovým pobytům do zahraničí. V té době se přitom jednalo prakticky výlučně o zahraniční odborné styky s pracovišti východoevropských zemích, a to převážně SSSR, PLR, NDR a MLR. ${ }^{22}$ Tehdejší zapojení členů katedry do vědecko-výzkumné činnosti také bylo, a to do značné míry organicky, spojeno s kvalifikačním růstem, resp. v určitých fázích vyúst'ovalo v jeho konkrétní projevy. Tak se nabízí uvést, že Miloslavu Mášovi byla v r. 1983 udělena vědecká hodnost doktora věd, Milanu Poliánovi byla v r. 1973 udělena vědecká hodnost kandidáta věd a docentem byl jmenován v r. 1977. Miladě Plškové byla vědecká hodnost kandidáta věd udělena v r. 1976 a docentkou byla jmenována v r. 1980. Milan Navrkal získal vědeckou hodnost kandidáta věd v r. 1977. Já jsem získal vědeckou hodnost kandidáta věd v r. 1985 a Jan Svatoň potom vědeckou hodnost kandidáta věd získal v r. 1987. Jako jistou zajímavost se v daných souvislostech nabízí uvést, že povinnou součástí zvyšování kvalifikace u mladých, resp. začínajících učitelů tehdy na brněnské univerzitě bylo, že v prvních třech až pěti letech svého působení měli předepsáno absolvování dvousemestrálního studia vysokoškolské pedagogiky na filosofické fakultě. Kromě mého absolvování tohoto studia, pokud si toto správně po létech vybavuji, dané studium z katedry dále absolvovali také Jan Svatoň a Helena Sýkorová.

Obor správního práva a postavení a pověst katedry správní vědy a správního práva v podmínkách brněnské právnické fakulty byly $\mathrm{v}$ dané době nesporně na nadprůměrné úrovni. Obor i katedra disponovaly odborným respektem, který se z mimofakultního pohledu opíral zejména o renomé odbornosti a výsledků tehdejší vědecké práce Miloslava Máši, a to včetně jeho zásluh o vybudování katedry na dané odborné úrovni. Své měli prürrozeně odpracováno i ostatní členové katedry a jmenovitě v této souvislosti nelze pro rozvoj oboru opomenout zejména dobový prŕnos Milana Poliána a Milady Plškové. Ve vnitrofakultním pohledu se potom odborná úroveň a respekt katedry projevovaly ponejvíce v jejich vnímání ze strany studentů, kterým bylo z vnějších ohlasů známo, že brněnští absolventi byli velmi žádáni a vítáni v praxi státní správy, a to pro jejich velmi dobrou odbornou připravenost. Znovu připomeňme, že předmět správní právo byl po celou tehdejší dobu povinným státnicovým předmětem a společně s občanským právem a trestním právem byl všeobecně považován za základ profilace absolventů tehdejšího právnického studia. $\mathrm{V}$ dané době také platilo, že o obor, či předmět, správní právo byl mezi studenty velmi výrazný zájem i při volbě a výběru témat diplomových prací. Bez významu pro zájem tehdejších studentů o správní právo přitom nebylo ani to, což se ostatně zprostředkovaně podává i z výše uváděného textu, že po celou tuto dobu bylo samozřejmostí, že katedra pro vyučované předměty disponovala jejich plným pokrytím vlastními studijními pomůckami. S mírnou

22 Ročenka Univerzity Jana Evangelisty Purkyně v Brně 1986-1987. Brno: UJEP, 1988, s. 268. 
nadsázkou řečeno tak bylo správní právo v dané době na brněnské fakultě nejen respektovaným, ale také „nepřehlédnutelným“ oborem.

Rok 1990 byl prrirozeně přelomovým rokem i pro obor správní právo a život i chod katedry. Celé následné období až do současnosti ze svého osobního pohledu vnímám jako období sestávající ze dvou částí. Jeho první část je představována léty 1990-2003, kdy jsem zastával funkci vedoucího katedry a kdy bylo potřeba nejprve katedru znovu personálně vybudovat, a to ruku v ruce s reformou oboru a jeho výuky. Druhá část tohoto období je pak představována etapou od poloviny roku 2003 do současnosti, kdy se obor i katedra, a to již pod vedením jiných vedoucích, ubíraly a ubírají dalšími reformními kroky a rozvojem.

Pokud jde o první z těchto etap (1990-2003), je v prvé řadě třeba připomenout, že katedra se hned na počátku r. 1990 personálně prakticky „rozpadla“. Na jaře r. 1990 byl z funkce vedoucího katedry uvolněn Miloslav Máša, pro obsazení funkce vedoucích kateder byl tehdejším vedením fakulty zaveden volební systém (volili členové katedry a vybírat mohli kohokoliv ze svého středu) a volba tehdy padla na mě. Současně byla na fakultě nastolena praxe, v jejímž smyslu měli odcházet do důchodu učitelé starší 65 let. Miloslav Máša, jemuž bylo 65 roků až v r. 1991, na fakultě sice setrval do dosažení uvedeného věku, nicméně stáhl se do ústraní, do výuky přiliš nevstupoval a spíše se věnoval studiu a vědeckému bádání. Milan Polián, ač 62letý, odešel do důchodu v polovině r. 1990 a ve stejné době do důchodu odešla i Milada Plšková, která již daného věkového limitu dosáhla. Jan Svatoň potom využil tehdejších možností a požádal vedení fakulty o přerazení na katedru ústavního práva, kde se chtěl věnovat svému „celoživotnímu“ odbornému zájmu, jímž byla státověda. Na katedru přitom bylo hned počátkem r. 1990 opět převedeno zpět ( $z$ tehdejší katedry hospodářského práva) finanční právo s Vladimírem Zahálkou, s nímž přišel ještě Pavel Matoušek. Za daného stavu jsem na katedře v té době zůstal na oborech správní věda a správní právo sám s Danou Šrubařovou a na oboru finanční právo, po odchodu Vladimíra Zahálky v r. 1992, zůstal působit Pavel Matoušek. $\mathrm{V}$ bezprostředně následujících letech byli na katedru pro obory správní věda a správní právo postupně přijati Soňa Skulová, Helena Veberová, Petr Mrkývka, Pavel Blažek a Petr Havlan, ${ }^{23}$ a pro obor finanční právo Pavel Malina. Ten však na katedře působil pouze krátce a společně s Pavlem Matouškem již v r. 1994 z katedry odešli. Na obor finanční právo přešel Petr Mrkývka a krátce nato k němu dále nastoupila Romana Št’astná. Na obory správní věda a správní právo dále nastoupily Ilona Kotisová, Monika Veselá (Horáková). Po odchodu Romany Št'astné, Heleny Veberové a Ilony Kotisové na počátku druhé poloviny devadesátých let katedru doplnili na finančním právu Ivana Pařízková a Alena Blažková, na správní vědě a správním právu Libor Nedorost, Stanislav Sedláček a na konci 90. let také Miluše Šebková, Jana Jurníková, Petr Kolman a Stanislav

23 Petr Havlan na katedře nejprve působil interně (1990-1992), poté do r. 1997 externě a od r. 1998 opět interně, a takto působí nepřetržitě dosud. 
Kadečka. V závěru uváděného období z katedry postupně odešli Alena Blažková, Libor Nedorost, Pavel Blažek a Miluše Šebková a obor finančního práva naopak posílili Michal Radvan a Dana Šramková. V uvedeném období katedra také spolupracovala s některými významnými externisty. $\mathrm{Na}$ oborech správní věda a správní právo se nabízí připomenout alespoň Petra Machálka, který se později začal výrazněji věnovat pracovnímu právu a právu sociálního zabezpečení, a na oboru finanční právo potom nelze v tomto směru nepřipomenout alespoň Alenu Schillerovou. ${ }^{24}$

Obory správní věda a správní právo, a to možná o něco více než jiné právní obory, jako obory bezprostředně spjaté s realizací výkonné moci ve státěe byly hned po přelomu r. 1989/1990 dynamizovány nabíhajícími proměnami veřejné správy. Tím bylo také, jak ostatně bylo ve své době (do jisté míry již retrospektivně) poznamenáno i v katedrové upoutávce v programu přednášek PrF MU v Brně 1993/1994, ${ }^{25}$ do jisté míry determinováno zaměření a charakter pedagogické a vědecko-výzkumné činnosti členů katedry, kteř́ zároveň s absorpcí četných změn v pozitivně právní úpravě usilovali nalézt a formulovat teoretická stanoviska a závěry, které by odpovídaly podmínkám moderního právního státu. Při tomto snažení nacházeli základ v pracích klasiků „našeho“ správního práva, jako zejména Františka Weyra, Adolfa Merkla, Jiřího Hoetzela a Jaroslava Pošváře a dalších, a zároveň také čerpali poznatky z tehdy dostupných zahraničních pramenů. V oblasti veřejné správy prritom bylo hned z počátku tohoto období zřejmé, že zásadní změny ve veřejné správě byly odstartovány reformou územní veřejné správy se zaměřením na revitalizaci samosprávy, přičemž jako další žádoucí reformní změny byly označeny očekávané reformy správního trestání, správního řízení a ve spojení s ním i správního soudnictví.

Za dané situace bylo také třeba výrazněji reformovat obsah a zaměření výuky správního práva, a to nejprve $\mathrm{v}$ magisterském studiu.

Výuka správního práva byla nově koncipovaná jako třísemestrová, přičemž byla rozdělena na dva předměty, a to na „dvousemestrové“ správní právo a veřejnou správu (včetně správního práva hmotného) a na ,jednosemestrové“ správní právo procesní. Z každého z těchto předmětů (oba byly seminarizovány a v seminářích uzavírány zápočty) se konala samostatná zkouška.

Předmět správni právo a veřejná správa zahrnoval obecnou část a zvláštní část (správní právo hmotné). V obecné části přitom byla věnována pozornost zejména základním pojmovým otázkám, nosným teoretickým institutům veřejné správy, základním správněvědním aspektům, funkcím metodám a formám činnosti veřejné správy, organizaci veřejné správy s důrazem na místní a také profesní či zájmovou samosprávu, záruky zákonnosti ve veřejné správě a podrobněji také i správněprávní odpovědnosti. Ve výuce zvláštní

24 Tč. je místopředsedkyní vlády a ministryní financí.

25 Právnická fakulta Masarykory univerzity v Brně 1993-94. Brno: MU, 1993, s. 47. 
části správního práva se potom pozornost zaměřovala na vybrané úseky hmotného práva podle jednotlivých oblastí, a to zejména na správu na úseku územního plánování a stavebního řádu, správu dopravy, správu živnostenskou, správu katastrální, správu na úseku vnitřních věcí, správu na úseku policie, správu na úseku obrany, správu na úseku školství, správu na úseku kultury a státní památkové péče a správu na úseku zdravotnictví. Přednášky z obecné části správního práva jsem z počátku daného období zabezpečoval převážně sám, ve zvláštní části správního práva se na přednáškách v dané době dále podílela zejména Soňa Skulová. Seminární výuku potom postupně vedli všichni učitelé katedry, kteři se v následujících letech již také podíleli na přednáškové výuce.

Předmět správníprávo procesni se potom vedle základních pojmových a systémových otázek a také nosných právně teoretických institutů zaměřoval zejména na rozbor právní úpravy tzv. obecného správního řízení a návazně na rozbor vybraných tzv. zvláštních úprav správního řízení. Nabízí se poznamenat, že brněnská právnická fakulta byla v té době jedinou fakultou u nás, která správnímu právu procesnímu ve výuce věnovala takovouto jmenovitou pozornost. Pro vedení přednášek a seminářů ze správního práva procesního v prezentovaném období života katedry v podstatě platilo totéž jako v prrípadě předmětu správní právo a veřejná správa.

Vedle těchto povinných předmětů katedra dále v dané době souběžně zabezpečovala také povinně volitelné předměty, a to správni vědu, správni právo trestni a záruky zákonnosti ve veřejné správě. Tyto předměty katedra zabezpečovala samostatně a mimo to se také podílela na výuce dvou dalších povinně volitelných mezikatedrových předmětů, jmenovitě předmětu soudni právo a správni soudnictví a právni aspekty podnikatelské činnosti. Postupně ještě přibyly samostatně katedrou zabezpečované povinně volitelné předměty mistni správa, veřejné stavebníprávo, stejně tak prédmèt správni soudnictví, resp. soudni kontrola verejné správy začala zanedlouho katedra vyučovat samostatně (současně však nadále daný předmět s jinou strukturou zabezpečovala i katedra občanského práva) a předmět právní aspekty podnikatelské činnosti byl přebudován na předmět právni aspekty živnostenskébo podnikání.

Vzhledem k profilové orientaci katedry byla ze zabezpečovaných povinně volitelných předmětů nejvýraznější pozornost vcelku přirozeně věnována správni védě, která na katedře „nahradila“ výuku předchozí (byt' správněvědně orientovanou) teorii ř̌zeni. ${ }^{26} \mathrm{~V}$ tomto v podstatě „,nově“ koncipovaném předmětu, který ve svém věcném zaměření dále rozvinul Mášovu koncepci správní vědy z poloviny 80. let, byl v návaznosti na základní správněvědní aspekty organizace a činnosti veřejné správy probírané v povinném správním právu kladen důraz na rozbor speciálních otázek spjatých s organizační strukturou veřejné správy i jejím faktickým fungováním. Předmět byl od tohoto samotného počátku jeho zabezpečování v podmínkách rozběhu reformy veřejné správy výrazněji teoreticky pojat, avšak nadále s propojením na aktuální otázky správní praxe.

26 Výuka vlastní „,teorie ř́zeni““ byla potom v modifikované podobě nadále vyučována na katedře národního hospodářství. 
Vedle tzv. magisterského studia je třeba ve spojení s počátky 90. let také připomenout podíl katedry na zabezpečování bakalářského studia. Shodou okolností, a to s ohledem na tehdejší společenskou poptávku, byla katedra správní vědy a správního práva první katedrou na fakultě, která připravila, rozběhla a úspěšně zabezpečovala bakalářské studium. ${ }^{27}$ Jednalo se o studium s názvem a také zaměřením Mistní správa, které se začalo zabezpečovat v r. 1992 a o které byl značný zájem z řad představitelů praxe místní správy. $^{28}$ Toto bakalářské studium za celou raadu let jeho dosavadní realizace absolvovaly stovky absolventů a nezrrídka mezi nimi byly i významné osobnosti z vedoucích pozic ve veřejné správě. ${ }^{29}$

Bakalářské studium mělo povahu tzv. dálkového studia, bylo koncipováno jako tř́leté a výuka byla rozložena do šesti semestrů. Většina předmětů byla zaměřena na problematiku správního práva a veřejné správy a její výuku z převážné části zabezpečovala sama katedra správní vědy a správního práva. Vyučovalo se formou přednášek, doplňovaných organizovanými pravidelnými konzultacemi ve tř́členných studijních skupinkách. Studium tak bylo spojeno s intenzivním osobním kontaktem mezi vyučujícími a studenty. Ukončovalo se státní bakalářskou zkouškou, spojenou s obhajobou diplomové práce,

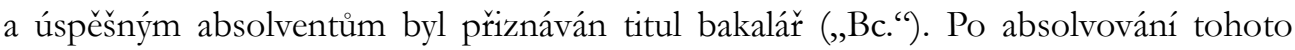
studia však nebylo možno studijně navázat a tzv. druhostupňově pokračovat ve studiu magisterském. ${ }^{30}$ Nicméně někteří absolventi tohoto studia se přesto pro magisterské studium rozhodli, i když je museli studovat celé, jakoby bakalářské studium předtím vủbec neabsolvovali. ${ }^{31}$

V prvních letech bylo toto bakalářské studium placené, přesto zájem o ně překračoval kapacitní možnosti fakulty. Později se podařilo zajistit jeho financování z rozpočtových zdrojů a s ohledem na poptávku z praxe bylo toto studium rozšířeno o další specializace, v jejichž rámci katedra také působila (a dodnes působî), ale v nich již zdaleka nespočívala

27 To je ostatně po nejrůznějších proměnách a modifikacích s významným podílem katedry zabezpečováno na fakultě dodnes. Nabízí se poznamenat, že při přípravě programu tohoto studia a v počátcích jeho rozběhu tento záměr napříč fakultou neměl zcela spontánní podporu a tehdejší představitelé dalších v úvahu přicházejících kateder se $\mathrm{k}$ tomuto studiu a aktivnímu zapojení do jeho výuky stavěli spíše zdrženlivě. Později, jak vyplývá z kontextu, se však i v tomto směru situace změnila.

28 Do prvního ročníku studia bylo zapsáno více jak sto studentů. Za poznamenání myslím stojí i to, že z úst vícerých účastníků studia tehdy nezř́idka zaznívalo, že jejich zájem o toto studium byl mj. motivován povědomím praxe státní správy o velmi dobré odborné úrovni katedrové výuky na brněnské právnické fakultě a jejîho ohlasu, a to zejména stran územní státní správy (to prritom ještě z doby v r. 1990 doživajících národních výborů).

29 Vedle mnohých starostů, dále i přednostů tehdejších okresních úřadů apod., se namátkou nabízí prripomenout jako jeho absolventy i pozdější ministry Tomáše Kvapila a Martina Rímana, kteří působili ve svých ministerských funkcích ve druhé polovině devadesátých let.

30 Toto se změnilo až počínaje šk. r. 2011/2012, od kdy je po předchozí akreditaci na fakultě realizováno (s katedrovým gestorstvím) tzv. navazující studium v oboru „Veřejná správa“.

31 Např. takto naším bakalářským studiem „Místní správa“, a posléze celým studiem magisterským, prošla i pozdější děkanka naši fakulty, Markéta Selucká. 
rozhodující odpovědnost zejména na ní. Při zpětném pohledu nelze nepoznamenat, že rozhodující podíl a zásluhy na vyjednání rozběhu bakalářského studia s tehdejším ministerstvem školstvím měl z vedení naší fakulty Jiří Klestil, který se na počátku 90. let opět vrátil na fakultu a krátce poté se stal jejím proděkanem.

Pro obsahově nově koncipované předměty, a to jak ve studiu magisterském, tak ve studiu bakalářském, byly také postupně zajišst'ovány př́íslušné studijní pomůcky. Jako první byla zpracována studijní pomůcka pro obecnou část správního práva, bezprostředně poté navázala studijní pomůcka pro zvláštní část správního práva, dále pro správní právo procesní, souběžně byla zpracována učební literatura pro správní vědu, ${ }^{32}$ stejně jako byly připravovány i studijní pomůcky pro některé další povinně volitelné předměty. ${ }^{33}$ Některé z těchto titulů, primárně zpracované pro magisterské studium, byly ve vymezovaném rozsahu doporučovány i pro studium bakalářské, jako specifický titul pro bakalářské studium byl v té době zpracován propedeutický text, jenž měl „uvést“ ke studiu místní správy. ${ }^{34}$ Většina těchto titulů studijní literatury byla v následujících letech, a to $\mathrm{v}$ některých př́padech opakovaně, postupně doplňována, aktualizována a také rozšiřována. Studium předmětů v oborech správní věda a správní právo tak bylo bezprostředně od počátku 90. let na brněnské právnické fakultě tedy přiměřeně zabezpečeno vlastní základní studijní literaturou, přičemž přirozeně byla doporučována ke studiu i učební literatura tehdejší pražské fakulty, popř. bratislavské fakulty, stejně jako byli studenti odkazováni i na literaturu časopiseckou.

Jak již bylo shora poznamenáno, $v$ předmětném období do působnosti katedry také náležel obor finanční právo. Vzhledem k meritornímu zaměření tohoto „ohlédnutî" na obor „správní právo“, resp. na obory správní věda a správní právo, toliko stručně poznamenejme, že i obor finanční právo byl náležitě výukově zabezpečován, jak předměty povinnými, tak předměty povinně volitelnými, a postupně byly pro výuku jednotlivých předmětů finančního práva zpracovány také vlastní učební pomůcky. To platí zejména pro období počínaje r. 1994, kdy se vedení oboru finanční právo ujal Petr Mrkývka. Jako zajímavost v této souvislosti uved'me, že cca od druhé třetiny 90. let až do r. 2007, kdy bylo „finanční právo“ opět převedeno na jinou katedru, jsme společně s finančním právem také zabezpečovali a zkoušeli „koordinovaný“ výukový povinný předmět Správní a finanční procesy.

Vrátíme-li se k organizaci výuky, zásadním novem od počátku tohoto období bylo, že byl opuštěn model stálých seminárních skupin, což mělo reálný odraz v seminární výuce.

32 PRŮCHA, P. Základy správního práva. Brno: MU, 1992, 167 s.; KOLEKTIV. Správní právo hmotné, vybrané kapitoly. Brno: MU, 1992, s. 219; PRŮCHA, P. Právni úprava spráuníbo ř́zení. Brno: MU, 1993, 58 s.; PRU゚CHA, P. a S. SKULOVÁ. Základy správního práva a veréené správy, procesnéprávni cást. Brno: MU, 1994, 175 s.; MRKÝVKA, P., P. PRŮCHA a S. SKULOVÁ. Vybrané kapitoly že správni védy. Brno: MU, 1993, $112 \mathrm{~s}$.

33 FIALA, J. a kol. Právni aspekty soukromého podnikání, skripta. Brno: MU, 1990, 83 s.; PRŮCHA, P. Mistní správa, vybrané otázky. Brno: MU, 1991, 142 s.; PRU゚CHA, P. Právni úprava prestupkư. Brno: MU, 1993,68 s.; FIALA, J. a kol. Živnostenské právo, skripta. Brno: MU - Doplněk Brno 1993, 146 s.

34 PRŮCHA, P. Úvod do studia mistní spráry. Brno: MU, 1992, 84 s. 
U tzv. stálých seminárních skupin $\mathrm{v}$ zásadě platilo, že se jejich složení během studia (až na neúspěšné studenty) prakticky neměnilo, a u vícesemestrálních předmětů učitelé studenty znali ze vždy předchozího semestru, což platilo přirozeně i naopak. To mělo své nesporné výhody, i když je nutno uznat, že silné zastánce si záhy získalo i nové organizační pojetí seminárních skupin.

V celém tomto období naproti tomu nadále platilo, že správní právo, jako významný profilový předmět právnického studia, bylo povinným státnicovým předmětem v rámci státní závěrečné zkoušky. S ohledem na tehdejší organizaci studia je třeba také připomenout, že správní právo bylo zkoušeno rovněž v rámci tzv. verejnoprávní blokové státní zkoušky.

Zmínit je třeba i skutečnost, že v souvislosti se změnami ve studijních programech došlo od počátku tohoto období, oproti stavu předchozímu, také k některým změnám v tzv. mimovýukové práci se studenty. $\mathrm{V}$ těchto souvislostech je potom třeba především poznamenat, že došlo k opuštění požadavku fakultou organizované odborné praxe studentů, což ve spojení s výukou správního práva znamenalo, že se studenti přestali setkávat s praxí činnosti reálné veřejné správy, což muselo být postupně reflektováno také ve zpo̊sobech vedení výuky. Zmínit je třeba i skutečnost, že v počátečních letech tohoto období byla také opuštěna pravidelná organizace SVOČ na celofakultní úrovni, na což jsme na katedře reagovali tak, že jsme organizovali alespoň katedrovou soutěž. Postupně se organizování SVOČ opět rozvinula např́íc celou fakultou, nutno však poznamenat, že k jejímu obnovení v takovém rozsahu a s takovým ohlasem, jako tomu bylo v 80. letech, již nedošlo. Nicméně to neznamená, že by SVOČ pozbyla na významu. Vedle činnosti pedagogické byla $\mathrm{v}$ daném období přirozeně věnována rovněž pozornost vědecko-výzkumné činnosti, spolupráci s katedrami správního práva domovských právnických fakult, jakož i zahraničním stykům.

Pro vědecko-výzkumnou činnost $\mathrm{v}$ dané době platilo, že se její organizační formy teprve postupně rodily a vytvářely, a vědecko-výzkumné zaměření členů katedry spíše operativně reagovalo na aktuální otázky teorie i praxe. Já osobně jsem se v dané době nejvýrazněji zaměřoval na problematiku místní správy a dále živnostenské správy, Soňa Skulová se věnovala správněvědním aspektům veřejné správy, otázkám správního uvážení, efektivnosti a zákonnosti rozhodovacích procesů, Petr Havlan se věnoval problematice majetku státu a územních samosprávných korporací, Pavel Blažek se věnoval problematice správního trestání, Jana Jurníková se věnovala cizinecké problematice a Stanislav Kadečka se věnoval normotvorbě územních samosprávných celků. To se nejvýrazněji odráželo zejména v publikační činnosti jednotlivých členů katedry, jejíž produkce byla v uváděném období poměrně značně početná. V závěru uvedeného období se potom již naskytla př́ležitost pro podíl na organizované vědecko-výzkumné činnosti a na katedře byly úspěšně realizovány dva granty: Grant z Fondu rozvoje vysokých škol MŠMT - Inovace studijních programů v oboru správní právo, roční projekt 2000/2001, řešitel Petr Průcha, spoluřešitel Soňa Skulová, a dále Grant z Fondu rozvoje vysokých 
škol MŠMT - Inovace studijních programů v oborech správní právo a správní věda, roční projekt 2001/2002, řešitel Soňa Skulová, spoluřešitelé Petr Průcha a Jan Svatoň.

$\mathrm{S}$ vědecko-výzkumnou, jakož i další odbornou činností katedry v dané době, souviselo i pokračování v tradici velmi dobrých vztahů s katedrami správního práva pražské, bratislavské a košické právnické fakulty, které zahrnovalo organizování a vzájemnou účast na nejrůznějších odborných konferencích, ale stejně tak i na společných zasedáních kateder a výměně učebních zkušeností. Výjimkou nebyly v té době i některé významnější akce mezinárodního dosahu. Tak lze hned ve vztahu k rokům 1991 (Turčanské Teplice) a 1992 (Brno) poukázat na lektorský podíl katedry na mezinárodních seminárích na téma Moderni mistni správa, realizovaných v rámci tehdejšího programu Tempus pod organizačním i obsahovým vedením představitelů Univerzity v Nöttingenu.

Brněnská katedra v dané době byla také sama organizátorem několika odborných konferencí s mezinárodní účastí, jmenovitě v r. 1993 (ve spolupráci s katedrou dějin) se jednalo o konferenci s názvem Historie a současnost verejné správy, v r. 1995 pak šlo o konferenci Soucaasnost a perspektivy mistni správy, v r. 1997 byla uspořádána konference K normotvorné pravomoci obcí a v r. 1999 se potom konala konference s názvem Aktuálni otázky reformy verejné spráry. Ze všech těchto konferencí také vzešly a byly vydány konferenční sborníky. Pokud šlo o tehdejší zahraniční styky katedry, opomenout nelze zejména, že hned na počátku 90. let byly navázány kontakty s Univerzitou v Salzburgu, dále s Univerzitou v Utrechtu a v polovině 90. let potom byly navázány kontakty s Univerzitou v Poznani, Univerzitou v Regensburgu, Univerzitou v Berlíně a také s Univerzitou v Oxfordu. Občasné kontakty byly $\mathrm{v}$ daném období realizovány rovněž s Univerzitou ve Vídni. Zahraniční styky katedry měly v dané době převážně formu studijních pobytů, v menším rozsahu šlo potom také o pobyty přednáškové.

Katedra v daném období poměrně intenzivně spolupracovala s pracovišti společenské praxe a výrazně se průběžně podílela i na externím vzdělávání volených představitelů i úředníků veřejné správy. Zvláště je třeba v tomto směru připomenout, že v závěru 90. let také sama pro představitele veřejnosprávní praxe zorganizovala a zabezpečila tři roky po sobě v prostorách fakulty vždy týdenní běh tzv. Letni školy veřejné správy. Od nich se potom návazně odvinuly další formy spolupráce katedry s veřejnoprávní praxí.

Zapojení členů katedry do vědecko-výzkumné a stejně tak i další odborné činnosti mělo přirozeně odraz i v tzv. kvalifikačním růstu jejich členů. Sám jsem hned na počátku r. 1990 získal vědecko-pedagogický titul docenta, což potom také umožnilo, abychom mohli na katedře nadále mít zachován status tzv. školicího pracoviště a vést vlastní „doktorandy“ ${ }^{35}$ Kromě vícerých externích frekventantů tzv. doktorandského studia touto

$35 \mathrm{~V}$ důsledku změn právní úpravy byla tzv. vědecká aspirantura s vědeckou hodností „CSc.“ změněna na doktorandské studium s vědeckou hodností nejprve „Dr.“ a krátce nato s vědeckou hodností „Ph.D.“, která je udělována dodnes. 
vědeckou výchovou $\mathrm{v}$ popisovaném období z členů katedry postupně prošli a doktorandské studium úspěšně ukončili v r. 1994 Soňa Skulová, 1996 Petr Mrkývka, Monika Veselá (Horáková) a Pavel Blažek, ${ }^{36} 1998$ Libor Nedorost a 2001 Stanislav Sedláček. Katedře zůstala zachována akreditace pro tzv. habilitační řízení a v r. 2001 pak ve spojení s tím získal Petr Havlan titul docenta.

Při zpětném pohledu stran zabezpečování oborů správní věda a správní právo na brněnské právnické fakultě v daném období (1990-2003) lze myslím souhrnně resumovat, že se katedru podařilo $\mathrm{v}$ zásadě nejen znovu personálně vybudovat, ale že se stejně tak $\mathrm{v}$ prriměřené míře podařilo oba obory správní věda a správní právo, jakož i výuku jejich předmětů, výrazněji reformovat. To se ostatně odráželo i ve veřejnosprávní složce profilu absolventa fakulty a jejich vybavenosti znalostmi k úspěšnému pracovnímu uplatnění jak v činnosti orgánů samosprávy, tak také v činnosti orgánů státní správy.

Ve vztahu ke druhé z těchto etap, tj. od r. 2003 do současnosti, myslím lze konstatovat, že již na jejím začátku byla katedra personálně vybudována a stabilizována a stejně tak byla vcelku zřetelně profilována jak v oblasti výuky, tak i v oblasti aktivit a zaměření členů katedry ve vědecko-výzkumné činnosti. Své viditelné místo katedra, prostřednictvím svých členů, v dané době zaujímala také ve společenské praxi, kdy se její členové aktivně podíleli na činnosti vědeckých rad, nejrůznějších odborných sborů a poradních orgánů a stejně tak i vícerých redakčních rad odborných periodik. Přirozeně i nadále platilo a platí, že obory správní věda a správní právo byly, a také i nadále jsou, v pedagogické i vědecko-výzkumné činnosti dále průběžně inovovány a rozvíjeny.

V polovině roku 2003 jsem byl jmenován soudcem Nejvyššího správního soudu, pracovní poměr mi byl na fakultě zachován, avšak bylo třeba jej redukovat na poloviční úvazek, ${ }^{37}$ a stejně tak bylo třeba ukončit moje působení ve funkci vedoucího katedry. Novou vědoucí katedry se stala Soňa Skulová, která tuto funkci, s výjimkou let 2010 až 2015, kdy byli vedoucími katedry Stanislav Kadečka a po něm Jan Svatoň (ač člen a vedoucí katedry ústavního práva a politologie), vykonává dodnes.

Pokud se jednalo o obměny personálního složení katedry, je třeba uvést, že v r. 2003, a to ve spojení s redukcí mého pracovního úvazku, byla na katedru přijata Alena Kliková, a dále pak byla katedra posílena až v r. 2009, ${ }^{38} \mathrm{kdy}$ na katedru nastoupila Veronika Kudrová (Smutná). Dalším novým členem katedry se potom v r. 2011 stal Lukáš Potěšil a k nejnovějším členům katedry, kteří nastoupili v průběhu posledních cca dvou až čtyř roků, patři David Hejč, Radislav Bražina, Anna Chamráthová a Tomáš Svoboda. V roce 2015

36 Nabízí se poznamenat, že Pavel Blažek se již tehdy také angažoval v územní samosprávě, poté byl a dosud je poslancem PČR a v letech 2012-2013 také vykonával funkci ministra spravedlnosti.

37 Na NSS působím dodnes a stejně tak dosud tento můj pracovní úvazek na fakultě trvá.

38 V mezidobí, a to v r. 2007, jak bylo ostatně již zmíněno shora, katedru opustili kolegové z finančního práva, a to v souvislosti s převedením oboru finančního práva na tehdejší Katedru národního hospodářství, dnes Katedra finančního práva a národního hospodářství. 
z katedry odešel Petr Kolman a na katedře se ve větší míře začala uplatňovat praxe kombinace tzv. celých a částečných pracovních úvazků. $\mathrm{V}$ důsledku toho tak v současné době na katedře působí osm členů katedry na celý úvazek a čtyři členové katedry na úvazek částečný (polovičnî).

Z inovací studijních programů, a to ve spojení se změnami ve struktuře a rozsahu výuky, je třeba poukázat především na změny v oblasti magisterského studia, ${ }^{39}$ jejichž postupný náběh a stabilizace doznívají dodnes a které byly ve své podstatě započaty počínaje šk. r. 2012/2013. Tehdy byl jako zcela nový předmět koncipován a zaveden Úvod do studia veřejné správy, s tím, že návazně budou restrukturovány $\mathrm{v}$ podstatě všechny předměty oboru správní právo, vyučované v tehdejším obsahu i rozsahu. Tak byl připraven, projednán a schválen program výuky správního práva, který v návaznosti na výuku „Úvodu...“ ve třetím semestru studia počítá s celkem třísemestrální výukou správního práva, zahrnující obecnou část (šestý a sedmý semestr), a dále tzv. zvláštní část (osmý semestr). Poté následuje společná zkouška. Mimo tuto výuku je ještě také relativně samostatně vyučováno Správníprávo procesni (sedmý semestr) se samostatnou zkouškou. Po obsahové stránce přitom vedle tradičního obsahu správního práva procesního tento předmět také zahrnuje procesní problematiku správního soudnictví. Se zaváděním takto inovovaného studijního programu správního práva do výuky bylo započato ve šk. r. 2016/2017.

Výuka uváděných předmětů je tradičně koncipována jako kombinace přednášek a seminárních cvičení, výjimkou je toliko „Úvod...“, který je studentům prezentován pouze ve formě přednášek. Ve spojení s tímto předmětem je třeba také poznamenat, že katedra se již od samotného zavedení tohoto předmětu do výuky snaží o jeho přeřazení pokud možno do pátého semestru, tedy tak, aby bezprostředně tato výuka předcházela obsahově navazující výuce správního práva. Toto snažení je bohužel zatím nevyslyšeno.

Jistou nevýhodou pro obor správního práva, jeho postavení ve výuce a jeho zprostředkovaný dopad do praxe absolventů, je potom, tady v poněkud jiném směru, to, že zhruba od r. 2010 není předmět správní právo povinným státnicovým předmětem, přičemž se katedra $\mathrm{v}$ bezprostředně posledním období o jeho znovuzařazení mezi povinné státnicové předměty také usilovně snaží.

V souvislostí s touto dosud poslední rozsáhlejší inovací studijního programu v oborech správní věda a správní právo byla rovněž inovována soustava povinně volitelných předmětů a u dřívějších z nich byl také přirozeně aktualizován jejich obsah. Podle současného stavu věci katedra v magisterském studiu nabízí a zabezpečuje následující povinně volitelné předměty: Správni véda, Mistni správa, Soudni kontrola verejné správy, Evropské správni právo, Verejný majetek, Diskrečni pravomoc verejné správy, Právotvorba verejéé správy, Právo na informace a ochrana osobnich údajü, Verejné stavebni právo, Vodní právo (mezikatedrový předmět),

39 Toto studium je koncipováno výlučně jako studium denní, s tím, že v odůvodněných prípadech lze žádat o umožnění studia podle individuálního studijního plánu bez pravidelné účasti na průběžně organizované výuce. 
Živnostensképrávo (mezikatedrový předmět), Pozemni komunikace a právo, Úvod od práva zpravodajských služeb a také Právo vysokých škol se zaměrením na správni rozhodování. Výuka a studium v těchto předmětech jsou ukončovány formou kolokvia.

Pokud jde o studium bakalárskéé, které je s katedrou nepřetržitě spojeno od r. 1992 (viz výše), to je v posledním období, po předchozích průběžných inovacích, představováno studijním programem Verejná správa se studijními obory Veřejná správa a Teorie a praxe trestního a správního procesu. ${ }^{40}$

Studium je koncipováno jako studium „při zaměstnáni““ s intervalově organizovanými výukovými bloky. Celé studium je tř́leté, je rozloženo do šesti semestrů a výuka jednotlivých předmětů je uzavírána zkouškami se stejnou stupnicí hodnocení jako ve studiu magisterském. Vyučované předměty jsou v převážné míre orientovány na problematiku veřejné správy a správního práva $\mathrm{v}$ celé jeho obsahové struktuře, a to včetně správněvědních aspektů veřejné správy. Celé bakalářské studium se ukončuje státní bakalářskou zkouškou, jejíž součástí je i obhajoba bakalářské práce. Výuka jednotlivých předmětů je zajišt'ována $\mathrm{k}$ němu určenými učebními pomůckami, tj. zpracovanými př́mo pro potřeby bakalářského studia, př́p. jsou ke studiu doporučovány ve vymezovaném rozsahu i učební prameny primárně určené pro studium magisterské. Absolventům bakalářského studia je přiznáván titul bakalář („Bc.“).

Od šk. r. 2011 prritom na brněnské fakultě platí, že absolventi bakalářského studia mohou po úspěšných príijímacích zkouškách ještě pokračovat ve studijním programu Verejná správa v tzv. navazujícím studiu. ${ }^{41}$ To rovněž gestorsky zabezpečuje katedra správní vědy a správního práva a také se současně ve značné míře podílí na výuce v něm. Tím se otevřela cesta pro absolventy (nejen) fakultních bakalářských studijních programů k dokončení jejich studia jako studia magisterského. Podmínkou pro přijetí do tohoto navazujícího studia přitom je, že uchazeč má absolvováno bakalářské studium právního směru, a to bez ohledu na to, na které z právnických fakult v České republice takové bakalářské studium absolvoval.

Toto navazující studium je žel koncipováno jako studium neprávního zaměření, realizováno je tzv. „při zaměstnání, organizováno je jako dvouleté, tzn. že výuka je rozdělena do čtyř semestrů. Velká část předmětů je zaměřena na studium organizace a činnosti veřjné spráry, a to včetně př́islušných provázaností na správní právo. Zvláštní pozornost a dưraz jsou potom věnovány či kladeny také na výuku a studium předmětu správni věda. Výuka je realizována prakticky výhradně formou přednášek, a to přirozeně s možností skupinových či individuálních konzultací. Studium je ukončováno státní závěrečnou zkouškou, včetně obhajoby diplomové práce, a úspěšným absolventům je přiznáván titul magistr („,Mgr.“).

40 Vedle toho je na fakultě realizováno bakalářské studium také v jiných studijních programech a také s gescí jiných kateder.

41 Jiné studijní programy bakalářského studia na brněnské právnické fakultě tzv. navazující studium akreditováno a organizováno nemají. 
Při prezentaci forem studia, v nichž naše katedra zabezpečuje výuku jednotlivých předmětů, nelze pominout ani studium postgraduální, které je na brněnské fakultě realizováno již rádově více než deset let, a to ve studijních programech MPA a LL.M. Z povahy věci je výraznější zapojení katedry ve výuce studijního programu MPA, kde je položen důraz právě na předměty oborového zaměření naší katedry.

Pokud jde o zabezpečení vyučovaných předmětů učební, resp. studijní literaturou, i pro toto současné období platí v podstatě totéž, co bylo uváděno ve vztahu k období předchozímu. Prakticky pro všechny předměty katedra disponuje vlastními učebními pomůckami, a to jak pro studium magisterské, tak také pro studium bakalářské. Pravidlem prritom je, že dané učební pomůcky jsou průběžně, a také opakovaně, v určitých časových intervalech aktualizovány a také rozšiřovány. V posledních cca deseti letech katedra disponuje také vlastní komentářovou literaturou ke klíčovým zákonům z oblasti správního práva (a to jak s výlučným autorstvím členů katedry, či s jejich významnějším spoluautorstvím), což nabídku vlastní katedrové studijní literatury významně rozšiřuje.

Vědecko-vzkumná činnost $\mathrm{v}$ tomto období již převážně probíhala a nadále probíhá $\mathrm{v}$ ustálených organizačních formách grantových projektů. Tady potom platilo, že se na řešení jednotlivých grantových projektů stř́idavě postupně podíleli prakticky všichni učitelé katedry. Př́kladmo tak lze poukázat zejména na následující grantové projekty: Grant GAAV ČR - Právní regulace financí a majetku územních samosprávných celků, 2001-2004, řešitel Petr Havlan, Grant MMR - Právní aspekty postavení obcí v oblasti bydlení, 2004/2005, řešitel Stanislav Kadečka, spoluředitelé Petr Průcha, Alena Kliková, Petr Kolman, Michal Radvan, Grant GAČR - Právní regulace místní samosprávy v České republice, 2006/2008, řešitel Stanislav Kadečka, spoluřešitelé Petr Průcha, Petr Havlan, Petr Kolman, Radomír Šimek, Grant MŠMT - Evropský kontext vývoje českého práva po vstupu do EU, 2006-2010, fakultní projekt - za katedru spoluřešitelka Soňa Skulová, Grant GAČR - Prostředky ochrany subjektivních práv ve veřejné správě, jejich systém a efektivnost, 2013/2016, řešitel - Soňa Skulová, spoluřešitelé Petr Havlan, Petr Průcha, Stanislav Kadečka, Alena Kliková, Lukáš Potěšil, David Hejč, Radislav Bražina a Tomáš Svoboda. Mimo tyto vybrané svou povahou významnější grantové projekty (tak, jak si je vybavuji či mám ve svých poznámkách), byly na katedře realizovány další projekty tzv. specifického výzkumu, projekty z Fondu rozvoje vysokých škol či projekty zaměřené na vzdělávání úředníků veřejné správy, přičemž některým tématům byla věnována pozornost i mimo organizované zapojení do vědecko-výzkumné činnosti. Tak lze poukázat zejména na zapojení Stanislava Sedláčka, který se dlouhodobě věnuje soudní kontrole veřejné správy, a na zapojení Jany Jurníkové, která se dlouhodobě věnuje cizineckému právu a také správě na úseku kulturních památek. Z aktuálních projektů, které se nabízí zmínit, tak běží, pokud je mi známo, zejména projekt technologické agentury ČR - Aplikace znalostí procesních obstrukčních taktik vyskytujících se zejména v řízení o dopravních přestupcích za účelem zvýšení efektivity řízení před správními orgány 
a zvýšení vymahatelnosti práva silničního provozu, 2018/2020, řešitel Lukáš Potěšil, a Projekt specifického výzkumu MUNI - Správní vyhoštění s důrazem na správní uvážení a neurčité právní pojmy, 2019, řešitel Radislav Bražina.

V tomto období katedra rovněž zorganizovala řadu konferencí a workshopů, které zpravidla vyústily ve vydání sborníků. Tak lze prripomenout jednak opakované konference v Kroměříži (před rokem 2010), spolupořádané s Kanceláří veřejného ochránce práv, které byly věnovány územní samosprávě a problematice správního řízení, a dále pak zejména konference pořádané od r. 2007 dosud ve spolupráci s Krajem Vysočina (a také v prostorách jeho úradu), se stálým názvem Spráuní rád v praxi krajských úradů, nicméně s postupně proměňovaným obsahem zaměřovaným na diferencované oblasti výkonu veřejné správy. Sluší se poznamenat, že jak tyto „kroměřížské“, tak tyto „jihlavské“ konference inicioval a zabezpečoval v rozhodující míre Stanislav Kadečka. Z dalších zřetelehodných konferencí organizovaných katedrou je myslím třeba připomenout mezinárodní konferenci Právni prostredky ochrany subjektivnich práv ve verejné správě, jejich systém a efektivnost (Means of Protection of Subjective Rights in Public Administration, Their System and Effectiveness) uspořádanou v r. 2016 v návaznosti na řešení předmětného grantového projektu. Iiniciátorem a garantem této konference byla Soňa Skulová. Opomenout nelze ani dvě významné celostátní konference k problematice vysokých škol a jejich právní úpravy v r. 2016 a 2018, jejichž iniciátorem a garantem byla Veronika Kudrová (Smutná).

V rámci kontaktů s odbornou praxí řada členů katedry působila či působí ve vědeckých radách a dále i v edičních či redakčních radách, expertních a poradních orgánech, katedra také nadále udržuje a rozvíjí spolupráci s nejrůznějšími teoretickými tuzemskými i zahraničními pracovišti. Z tuzemských pracovišt' jde v prvé řadě o všechny stávající právnické fakulty našich veřejných vysokých škol a ze zahraničních pracovišt' potom jde v posledním období zejména o Univerzitu v Poznani a o Univerzitu v Lublani. Zmínit je třeba rovněž zapojení několika členů katedry pod vedením Soni Skulové do činnosti European Group for Public Administration (EGPA), regionální skupiny International Institute of Administrative Sciences se sídlem v Bruselu, a ve spojení s tím i jejich opakovanou účast na výročních konferencích EGPA. Obdobně je možné také připomenout aktivní členství Stanislava Kadečky v Group of Independent Experts on the European Charter of Local Self-Government, se sídlem ve Štrasburku.

Pro vědecko-výzkumnou a odbornou činnost členů katedry $\mathrm{v}$ tomto posledním období je také charakteristická poměrně rozsáhlá publikační činnost členů katedry, ${ }^{42}$ a to včetně členů katedry, kteří patří k tzv. pracovně nejmladším. S tím je spojen i kvalifikační růst členů katedry. V průběhu sledovaného období proběhla žel jediná habilitace,

$42 \mathrm{~V}$ dalších podrobnostech, a to jak pokud jde o publikační činnost nebo zapojení do odborné a expertní činnosti při spolupráci s praxí či další zahraniční styky apod., lze myslím odkázat na oficiální fakultní evidence a přehledy a také na dokončený, a tč. se v tisku nacházející 2. díl Dějin právnické fakulty, zpracovaný právě při prŕležitosti nynějšího výročí jejího znovuobnovení. 
a to v r. 2004, kdy habilitovala Soňa Skulová. Já jsem potom v r. 2008 absolvoval profesorské řízení, ${ }^{43} \mathrm{a} \mathrm{v}$ průběhu let úspěšně ukončilo několik členů katedry tzv. vědeckou přípravu a získali vědeckou hodnost „Ph.D.“. Od r. 2003 dosud takto z učitelů katedry danou vědeckou hodnost získali postupně Jana Jurníková, Stanislav Kadečka, Alena Kliková, Petr Kolman, Veronika Kudrová (Smutná), Lukáš Potěšil, David Hejč a Radislav Bražina (všichni tzv. na domácí půdě). Vědeckou výchovou na katedře tč. prochází Tomáš Svoboda a Anna Chamráthová.

Odborná i společenská činnost některých členů katedry v tomto období také nalezla svůj výraz i ve vnějším individuálním ocenění. Tak lze zejména připomenout, že Stanislav Kadečka již za r. 2004 obdržel Cenu rektora Masarykovy univerzity za vynikající výsledky v doktorském studiu, Stanislav Sedláček, který se dlouhodobě mimo své právnické profese věnuje výtvarné tvorbě a zapojuje se do charitativní činnosti, v r. 2013 obdržel Stříbrnou medaili rektora Masarykovy univerzity, já jsem za r. 2013 obdržel titul „Právník roku“ v oboru správní právo a tentýž titul za r. 2015 poté obdržel i Stanislav Kadečka.

I toto je myslím do jisté míry potvrzením skutečnosti, že katedra správní vědy a správního práva brněnské fakulty je i v posledním období uznávaným a také plně respektovaným odborným vysokoškolským pracovištěm, a to nejen $\mathrm{v}$ rámci fakulty a našî univerzity, ale i z pohledu vnějšího prostředí. A to jak v oblasti pedagogické, tak také v oblasti vědecko-výzkumné a stejně tak pokud jde o její celkovou společenskou prestiž. A to nejen prestiž formální, ale i neformální. To je přitom zcela nepochybně zásluha všech, kdo se na její činnosti podílí.

Pod tímto zorným úhlem potom vše také myslím nasvědčuje tomu, že díky v poslední době kvalitně doplněnému personálnímu složení má katedra z hlediska zajišt’ování svého chodu a stále potřebného rozvoje vcelku dobré vyhlídky i do dalších let a příznivou perspektivu.

Svoje „ohlédnutí“ za 50letým vývojem oboru „správní právo“ a katedry správní vědy a správního práva rád uzavírám se zřetelně převažujícím uznáním všeho, co bylo za celá tato léta vykonáno a čeho bylo dosaženo. Stejně tak pozitivně vnímám i přinejmenším nejbližší dohlédnutelnou budoucnost.

Katedra tedy jubiluje ze zřetelnou perspektivou. Co k této perspektivě ,jubilantce“ popřát? Budu stručný a „jubilantce“ přeji stále „dobrou kondici“, po všech stránkách. A to přinejmenším jako dosud.

43 Vzhledem k tomu, že naše fakulta nedisponuje akreditací pro profesorské řízení z oboru správní právo, dané ř́zení se konalo v Bratislavě. 